Original Paper http://ajol.info/index.php/ijbcs http://indexmedicus.afro.who.int

\title{
Comparative study of some physical properties of the shea kernels in the shea parks in Benin
}

\author{
Roger Houéchénè AHOUANSOU ${ }^{1,2 *}$, Pelagie Bidossessi AGBOBATINKPO ${ }^{1,3}$, Emile \\ Adjibadé SANYA ${ }^{2}$, Benoit GNONLONFIN ${ }^{1}$ and Pascal FANDOHAN ${ }^{1}$ \\ ${ }^{1}$ Programme on Agricultural and Food Technology (PTAA), National Institute of Agricultural Research of \\ Benin (INRAB), POB: 128, Porto-Novo, Republic of Benin \\ ${ }^{2}$ Laboratory of Applied Energetic and Mechanic (LEMA) - Polytechnic School of Abomey-Calavi (EPAC) - \\ University of Abomey-Calavi-UAC) 01 POB:2009 Cotonou (Benin) \\ ${ }^{3}$ Laboratory of Food Sciences (LSA)- Faculty of Agronomic Sciences (FSA)- University of Abomey-Calavi- \\ UAC) 01 BP 526 Cotonou (Benin) \\ *Corresponding author; E-mail: gnankis@yahoo.fr, Tel: (+229) 97986253
}

\begin{abstract}
In Benin Republic, there are five different known shea parks. The dedicated various studies to the characterization of nuts and kernels in Benin, and in the sub-region, are often limited to the samples taken from only one zone and did not take into account the variability of the production zones. This study aimed at assessing the physical properties of shea kernels collected in four shea parks of Benin. Sizes (length, width, thickness), one-thousand nuts weight, the true and bulk volumes, sphericity, porosity and the true and bulk densities, have been determined on shea kernels from each park using appropriate methodology. The results showed that average moisture content of the shea kernels was $7.55 \pm 1.23 \%(w b)$. The parks of Kandi and Savè displayed the smallest shea kernels while those from Parakou and Bembèrèkè, showed the biggest. Sphericity of shea kernels turns around 0.72 whereas their porosity ranges from 41.59 to $43.24 \%$ and the weight of onethousand kernels ranges from 3.98 to $4.40 \mathrm{~kg}$. The true and bulk volumes of one-thousand kernels vary from 3.88 to $4.37 \mathrm{dm}^{3}$ and 6.64 to $7.70 \mathrm{dm}^{3}$ respectively. The true and bulk densities fluctuate from $1,007.51$ to $1,024.24 \mathrm{~kg} / \mathrm{m}^{3}$ and 571.77 to $598.12 \mathrm{~kg} / \mathrm{m}^{3}$ respectively. These results call for-the development of appropriate equipment for shea processing in Benin.
\end{abstract}

(C) 2016 International Formulae Group. All rights reserved.

Keywords: Sizes, sphericity, porosity, true density, specific area, one-thousand kernels.

\section{INTRODUCTION}

Shea (Vitellaria paradoxa) and locust bean (Parkia biglobosa) are the main trees in the reserved parklands of northern Benin (Agbobatinkpo et al, 2012; Koura et al. 2013). They represent a true component of the forest resources, both from a socioeconomic and nutritional perspective (Honfo et al., 2013; Fatoumata et al., 2016), and ecological
(Adéola, 2011) in West Africa. The marketing of processing products generates significant income for rural families (Honfo et al, 2012; Abdul, 2013; Ouattara, 2015). But the degradation due to human activity (Gnanglè et al, 2016) and parasites (Boussim et al., 2012) are among the constraints for managing of these parks. 
Shea nuts tree is a member of the Sapotaceaes family (Oluwolé et al., 2007) commonly found in Africa. Benin Republic is one of the sixteen countries that produce shea kernels in Africa (Nde Bup et al., 2014). The share of production of shea kernels, in Benin in 2003, was estimated to $2 \%$ of the West African production ene. This remains very feeble compared with that of Nigeria $(61 \%)$. Others countries including Mali (12\%), Burkina Faso (10\%), Ghana (9\%) and Cote d'Ivoire $(5 \%)$ are also producer of the shea nuts (CNUCED, 2008). The Benin exports of shea kernels were estimated to \$US 128,000 in 2007 (FAOSTAT, 2010).

The sweet and edible pulp of the shea fruit is widely consumed and is a rich source of sugars, proteins calcium, ascorbic acid and iron (Maranz and Wiesman, 2004; Makalao et al., 2015). The shea tree is mainly important for its kernels as it is processed into shea butter, a very important vegetable oil in West Africa (Kouyaté et al., 2015). Today, 95\% of shea kernels marketed, across world market, are destined to the agro-food sector (Rantrua, 2004; Honfo et al., 2014). In Europe, shea butter is used in chocolate factory, in pharmacology for making cosmetics and various types of creams. In rural areas the shea tree is an opportunity, particularly for women, in the fight against poverty (Tiamiyu et al., 2014). Despite of its importance, there are many challenges pertaining the development of the African shea kernels sector especially the lack of efficient processing technologies (Bup et al., 2014; Tame et al., 2014). For this reason, producer countries of shea kernels often, transform locally less than a third of their production potential, due to the lack of improved techniques (Gnanglè, 2005). Traditionally, shea kernels are obtained by pounding kernels in a mortar or with stone. Then shea butter is extracted following the operations of grinding or crushing, roasting and milling of kernels, churning of the obtained dough and cooking of the cream (Singbo and Ahouansou, 2005). The above described processing method is cumbersome and is often done by women. Locally manufactured and research out made equipment assist in alleviating the challenges facing processors. But the conception and the realization of efficient equipment are not possible without adequate knowledge on the physical and mechanical properties of the shea kernel, nut and dough, the performances of processing equipment being deeply linked with these parameters. The technical specifications of agricultural product constitute important parameters in the process of manufacturing equipment (Meisami-asl et al., 2009). Several studies have been carried out on the physical characterization of shea kernels and their kernels (Yê et al., 2004; Aviara et al., 2005; Ahouansou et al.,). Results revealed some variabilities of the product properties, at physical and mechanical, and notably dimensional levels, all these having been attributed to geographical and climatic features of the production zones. But these studies have been conducted on pooled samples taken at village or Department level seales. Therefore, countrywide aspects were not considered. For instance, Ahouansou et al. (2008) who worked on samples collected in the village of Simpérou in Banikoara (North of Benin) or Aviara et al. (2005) on kernels collected at Michika in Adamawa state (Nigeria), and for Yê et al. (2004) who investigated physical properties of shea kernels collected at Santidougou located at $15 \mathrm{~km}$ of Bobo Dioulasso (Burkina). In Benin, five shea parks are recognized: Bohicon, Kandi, Bembèrèkè, Parakou and Savè. In the fifth park of Benin, that of Bohicon, shea products are very less valorised (Gnanglè, 2005).

The present study intends to evaluate the physical properties of shea kernels collected in four shea parks of Benin relevant for the conception of high-performance and adapted processing equipment that could be used at national level.

\section{MATERIALS AND METHODS Study areas}

This study was carried out in four out of five shea parks of Benin: Kandi, Bembèrèkè, Parakou and Savè. The geographic characteristics of the study zones 
and physical parameters (density and diameter) of shea trees, that populate these various parks, are shown in Figure 1 and Table 1.

\section{Biological materials}

Shea kernels were collected in the four cited shea parks of Benin. Samples were taken randomly from processors in 24 villages. Six (6) villages per shea park and three (3) processors per village. Five (5) $\mathrm{kg}$ of shea kernels were taken from each processor, properly packed and transported to the Laboratory for analysis.. Physical analyses were carried out in the laboratory of the Programme on Agricultural and Food Technology (PTAA) of the National Institute of Agricultural Research of Benin (INRAB).

\section{Methods \\ Determination of physicals properties of shea kernels}

Physical characterization of the collected shea kernels was carried out through determination of moisture content, size (length, width and thickness), volumes, weight, true and bulk densities.

Moisture content was determined using the ISO 662:1998 Standard. Shea kernels were ground in a RETCH mill for three minutes. Three sub-samples samples of $10 \mathrm{~g}$ each were subjected to oven drying at $103 \pm 2{ }^{\circ} \mathrm{C}$ for $17 \pm 1$ hours, as shea kernels belong to seeds containing high percentage of oil. For this, a HOH-EXPRESS HE50, PFEUFFER, GERMANY oven was used, samples being kept closed in an ISO 9001 desiccator, for cooling during $15 \mathrm{~min}$, before each weighing step, mainly at drying end time.

The average sizes (length, width and thickness) of kernels were determined using a FACOM calliper with an accuracy of 0.01 $\mathrm{mm}$. These measures have focused on a sample of 100 almonds randomly selected therefore 2,400 kernels from each shea park. Shea kernels (Figure 2), having an oblong shape, the size fixing was achieved from the position of balance that is often, either the face of the germ, or the one opposite. Thus, the kernels thickness (t) is the distance between the horizontal and parallel plans $\mathrm{P}_{1}$ and $\mathrm{P}_{1}$ '. The first is the plan of rest of the kernel and the second pass by the opposed superior point. The kernels length (L) is the highest distance between the two vertical and parallel plans $\mathrm{P}_{3}$ and $\mathrm{P}_{3}$, passing on the extreme points of the kernel while the width (w) is the lowest distance between the plans $P_{2}$ and $\mathrm{P}_{2}$.

Knowing the average sizes of kernels, the following parameters were determined (Ahouansou et al., 2012):

$\checkmark$ Elongation of kernel (E):

$$
E=L / l
$$

(1)

$$
\checkmark \text { Degree of flattening (F): } \quad A=l / e
$$

(2)

$$
\begin{aligned}
& \checkmark \text { Mean Arithmetic diameter }\left(\mathrm{D}_{\mathrm{a}}\right) \text { : } \\
& D_{a}=(L+l+e) / 3 \quad(\mathrm{~mm}) \\
& (3) \\
& \checkmark \quad \text { Mean Geometric diameter }\left(\mathrm{D}_{\mathrm{g}}\right) \text { : } \\
& \quad D_{g}=(L \times l \times e)^{\frac{1}{3}}(\mathrm{~mm}) \\
& \checkmark \text { Sphericity of kernel }(\mathrm{S}): S=(L \times l \times e)^{\frac{1}{3}} / L
\end{aligned}
$$

Where L, 1, e, respectively the length, width and the thickness of the kernel.

The one-thousand kernels weigh was measured according to the ISO 520:1977 standard using an electronic weighing machine with precision of to $0.001 \mathrm{~g}$. The true density on one-thousand kernels was obtained with a Bruckner pycnometer filled with xylene $\left(\mathrm{C}_{8} \mathrm{H}_{10}\right)$. A sample of 100 kernels, previously weighed $(\mathrm{m})$, was poured in the xylene and the volume (V) of liquid displaced in the pycnometer was read. Then, the true density $(\rho)$ was calculated from the following relationship:

$$
\rho=m / V \quad\left(\mathrm{~kg} / \mathrm{m}^{3}\right)
$$

The volumes of one-thousand kernels provide estimates of average volume $\left(\mathrm{V}_{\mathrm{z}}\right)$ of a single kernel. Knowing the average volume and the true density of a kernel leads to the 


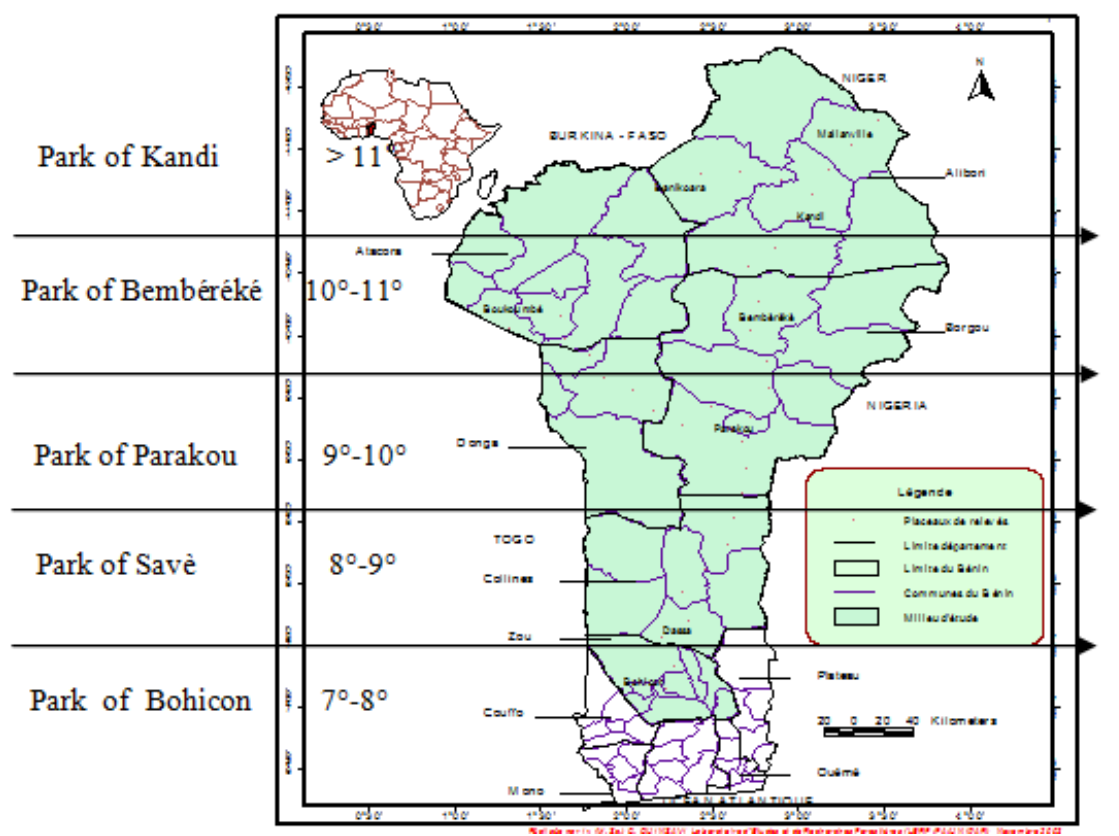

Figure 1: Geographic characteristics of the study zones.

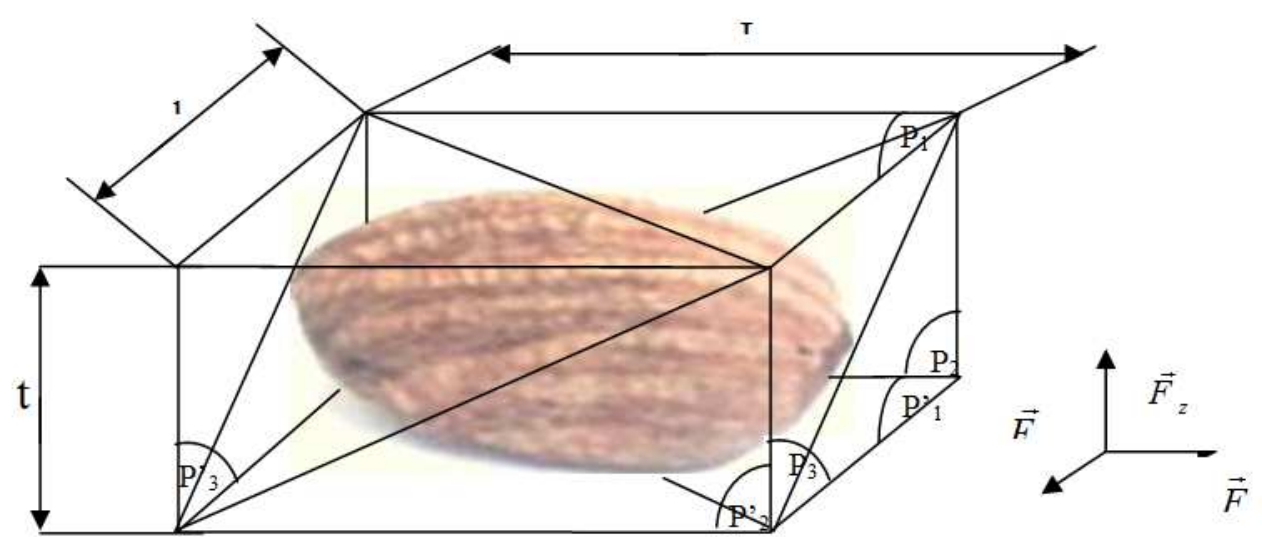

Figure 2: Definition of sizes of shea kernels.

Table 1: Characteristics of the targeted shea parks in Benin.

\begin{tabular}{lcc}
\hline Shea parks (zone names) & Tree mean density (trees/ha) & Mean diameter $\mathbf{( c m )}$ \\
\hline Savè & 26 & 28 \\
Parakou & 27 & 31 \\
Bembéréké & 41 & 29 \\
Kandi & 31 & 49 \\
\hline
\end{tabular}


estimation of shape parameters defined by the following equations Ahouansou et al., 2012):

$$
\begin{gathered}
D_{E}=1,24 \sqrt[3]{V_{z}} \quad(\mathrm{~m}) \\
\quad \begin{array}{l}
\text { Specific area }\left(S_{m}\right): \\
S_{m}=6 / \rho D_{E} \quad\left(\mathrm{~m}^{2} / \mathrm{kg}\right)
\end{array}
\end{gathered}
$$$$
\checkmark \quad \text { Equivalent diameter }\left(D_{E}\right) \text { : }
$$

(8)

$$
\begin{aligned}
& \checkmark \quad \text { Specific volume }(\mathbf{S}) \text { : } \\
& S=6 / \rho \quad\left(\mathrm{m}^{3} / \mathrm{kg}\right)
\end{aligned}
$$

(9)

The bulk density $\rho_{0}$ of shea kernels was determined so as they were stuck in a container of known volume. A weighed kernels $\left(\mathrm{m}_{0}\right)$ was poured into a graduated cylinder, packed and the occupied volume $\left(\mathrm{V}_{\mathrm{b}}\right)$ was then read.

$\checkmark \quad$ Bulk density

$$
\rho_{0}=m_{0} / V_{b} \quad\left(\mathrm{~kg} / \mathrm{m}^{3}\right) \quad(10) .
$$

The porosity $\left(R_{\mathcal{\varepsilon}}\right)$, when it is subjected to any external pressure, was calculated using the following formula:

$$
R_{\varepsilon}=100 \times\left(\rho-\rho_{0}\right) / \rho \quad(\%)
$$

\section{Statistical analysis}

Statistical computer program, SPSS 12.0, was used for statistical analyses. Mean values and frequencies were computed for data including moisture content, size (length, width, and thickness), volume and weigh, true and bulk density. Parameters that verify, Kolmogorov-Smirnov normality and Levene homogeneity of variance tests, were subjected to analysis of variance, using StudentNewman-Keuls for structuring obtained mean-values. The other parameters, which have not respected the normality and homogeneity conditions of variance, were subjected to nonparametric tests of KruskalWallis. The p-value was indicated for significant difference. (Glèlè Kakai, et al., 2006; Glèlè Kakai et al., 2004).

\section{RESULTS}

Moisture content and sizes of shea kernels

Moisture content and measures of shea kernels collected in the four explored shea parks of Benin are shown in Table 2 . Moisture content of shea kernels varies between $7.53 \%$ and $7.95 \%$ with a mean-value of $7.55 \pm 1.23 \%$. These moisture contents, although statistically different from one park to another, remain lower than that of WEAMU standard (2005) of $9 \%$.

Shea kernels sizes also vary according to the shea parks ranging from 26.23 to $27.29 \mathrm{~mm}, 17.70$ to $18.68 \mathrm{~mm}$ and 14.33 to $15.18 \mathrm{~mm}$ for length, thickness and width, respectively. The kernel from Bembereke park are the largest while those from Kandi park, smallest. From one arc to another, the mean value of moisture content, length, width, and thickness of the kernel are stastically different at $5 \% \quad$ (p-value=0). Similarly for the mean arithmetic and geometric diameters. The park of Bembèrèkè presents biggest values for the shea kernels sizes, while the park of Kandi displays the smallest ones. This variability could be linked to measures of the shea trees, mainly their diameters, as shown in Figure 2.

The data shows that the shea trees of biggest diameters produce smallest shea kernels. So, according to the recorded results, the polynomial function that adequately fits the data from the evolutions of shea kernels measures (length, width and thickness), respective versus the average diameter of shea trees $(d)$, may be represented by the following equations:

$$
\begin{aligned}
& L=-0,26 d^{2}+1,012 d+26,36 \\
& \mathrm{~mm}) \\
& (12) \\
& t=-0,37 d^{2}+1,36 d+18,105 \\
& \quad(\mathrm{~mm}) \\
& (13) \\
& w=-0,232 d^{2}+0,9835 d+14,103 \\
& (\mathrm{~mm})
\end{aligned}
$$

with regression coefficients of $R^{2}=0.99$ for $\mathrm{L}, \mathrm{R}^{2}=1$ for $l$ and $\mathrm{R}^{2}=0.99$ for $\mathrm{w}$ and where $\mathrm{L}, t$, and $w$ representing the shea nut length, thickness and width $(\mathrm{mm})$ and $\mathrm{d}(\mathrm{m})$ the shea tree average diameter in the parks, respectively. 
It was also noticed that evolutions of the mean arithmetic diameter and mean geometric diameter are relatively similar to that of equivalent diameter. All parameters follow similar trends like for the kernels measures.

\section{Shape parameters of shea kernels}

Shape parameters of the analysed shea are presented in Table 3. Shea kernels elongation varies between 1.82 and 1.86 while their flattening is around $0.81 \pm 0.13$. Subsequently, the length of shea kernels is, on average, 1.84 times the width, while almond width also remains 0.81 times the thickness.

Regarding the sphericity the analysed shea kernels are (27-28\%) far to be considered as spherical shaped. Indeed the results show that the shapes are similar to that of a sphere $(72-73 \%)$.

\section{Mass and volume parameters}

Mass and volume are presented in Table 4. Shea from parks of Savè and Kandi provide the lightest kernels. Parakou and Bembèrèkè produce the heaviest shea kernels.

The volume of 1000-shea kernels varies between 3.76 and $4.37 \mathrm{dm}^{3}$ with a mean-value of $4.09 \pm 0.5 \mathrm{~cm}^{3}$. There was no statistically significant difference, between the true density and bulk density of the shea kernels from the parks of Savè and Kandi in the one hand, and shea kernels from the shea parks of Parakou and Bembèrèkè, on the other hand. The density of shea kernels varies between 1.01 and 1.02 .

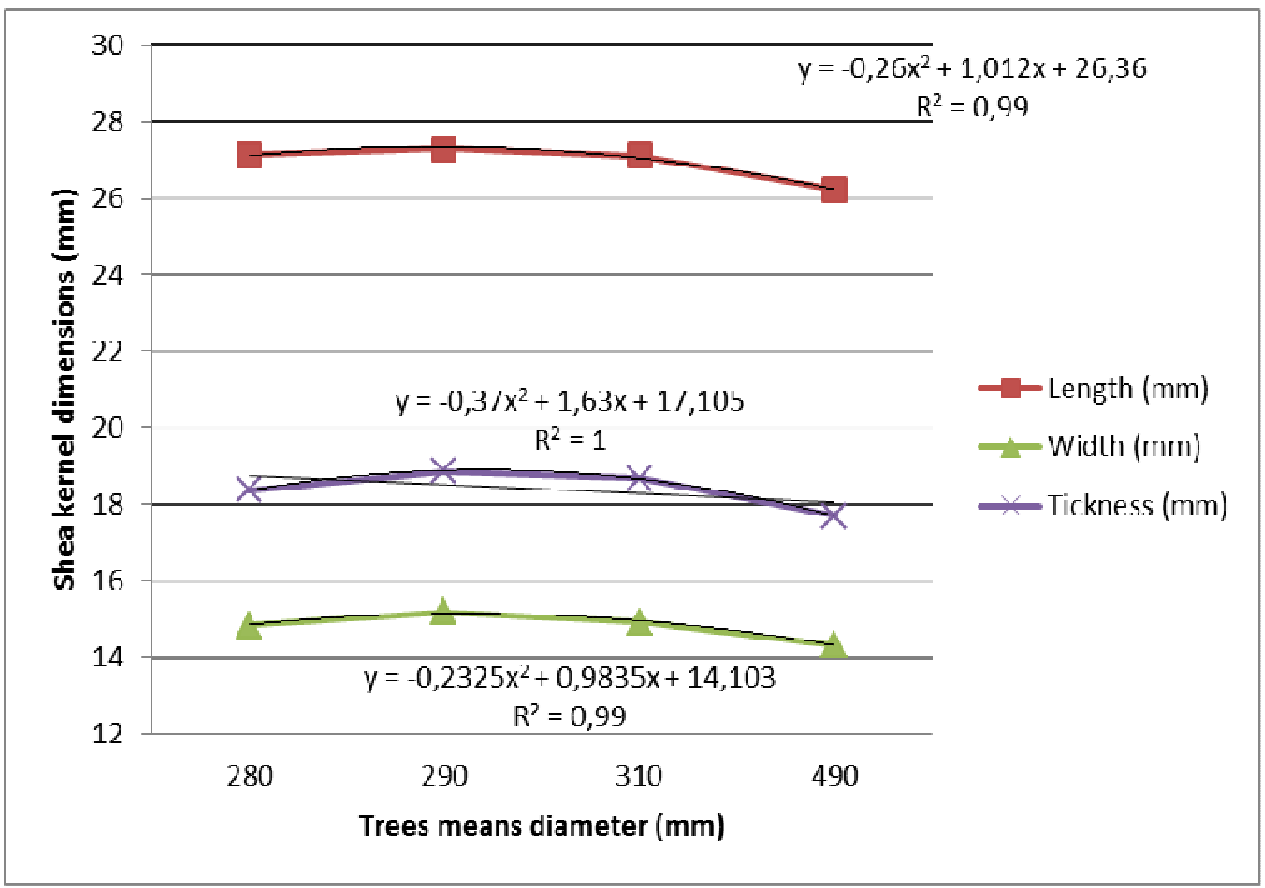

Figure 2: Relationship between the nuts sizes and average diameter of shea trees. 
R. H. AHOUANSOU et al. / Int. J. Biol. Chem. Sci. 10(5): 2151-2162, 2016

Table 2: Moisture content and size of analysed shea kernels.

\begin{tabular}{|c|c|c|c|c|c|c|c|}
\hline Parks & $\begin{array}{l}\text { Moisture } \\
\text { content }(\%)\end{array}$ & $\begin{array}{l}\text { Length } \\
(\mathrm{mm})\end{array}$ & $\begin{array}{l}\text { Thickness } \\
(\mathbf{m m})\end{array}$ & $\begin{array}{l}\text { Width } \\
\text { (mm) }\end{array}$ & Arithmetic mean Diameter (mm) & $\begin{array}{l}\text { Geometric } \\
\text { mean } \\
\text { Diameter } \\
(\mathrm{mm})\end{array}$ & $\begin{array}{l}\text { Equivalent diameter } \\
(\mathrm{mm})\end{array}$ \\
\hline Savè & $7.55 \pm 1.21$ & $27.13 \pm 3.19$ & $18.37 \pm 2.07$ & $14.84 \pm 1.93$ & $20.11 \pm 1.84$ & $19.42 \pm 1.76$ & $19.47 \pm 0.68_{a}$ \\
\hline Parakou & $7.53 \pm 1.42$ & $27.11 \pm 3.80$ & $18.68 \pm 6.03$ & $14.92 \pm 2.20$ & $20.24 \pm 2.89$ & $19.51 \pm 2.23$ & $20.15 \pm 1.12_{b}$ \\
\hline Bembèrèkè & $7.119 \pm 1.17$ & $27.29 \pm 3.46$ & $18.87 \pm 2.39$ & $15.18 \pm 2.16$ & $20.45 \pm 2.10$ & $19.78 \pm 2.04$ & $20.24 \pm 0.88_{b}$ \\
\hline Kandi & $7.95 \pm 0.97$ & $26.23 \pm 3.62$ & $17.70 \pm 2.45$ & $14.33 \pm 2.27$ & $19.42 \pm 2.28$ & $18.73 \pm 2.29$ & $19.26 \pm 0.69_{\mathrm{a}}$ \\
\hline Mean & $7.55 \pm 1.23$ & $26.93 \pm 3.55$ & $18.41 \pm 3.65$ & $14.82 \pm 2.17$ & $20.05 \pm 2.34$ & $19.36 \pm 2.13$ & $19.78 \pm 0.95$ \\
\hline $\mathrm{P}$-value & 0.00 & 0.00 & 0.00 & 0.00 & 0.00 & 0.00 & \\
\hline
\end{tabular}

Mean with the same letters $(\mathrm{a}, \mathrm{b})$ on row are not significantly different at $\mathrm{P}=0.05$ depending of Student Newman Keuls test. Those that are not assigned the letter have suffered the nonparametric KruskalWallis test.

Table 3: Shape parameters of the analysed shea kernels from different parks in Benin.

\begin{tabular}{lcccc}
\hline Shea parks & Elongation & Flattening & Sphericity & Porosity $(\boldsymbol{\%})$ \\
\hline Savè & $1.85 \pm 0.30$ & $0.81 \pm 0.11$ & $0.72 \pm 0.05$ & $41.59 \pm 3.08$ \\
Parakou & $1.84 \pm 0.38$ & $0.81 \pm 0.12$ & $0.72 \pm 0.06$ & $42.37 \pm 2.49$ \\
Bembèrèkè & $1.82 \pm 0.31$ & $0.82 \pm 0.16$ & $0.73 \pm 0.06$ & $43.24 \pm 1.47$ \\
Kandi & $1.86 \pm 0.33$ & $0.81 \pm 0.11$ & $0.72 \pm 0.07$ & $42.51 \pm 2.47$ \\
\hline Mean values & $1.84 \pm 0.33$ & $0.81 \pm 0.13$ & $0.72 \pm 0.06$ & $42.43 \pm 2.48$ \\
\hline P-value & 0.00 & 0.42 & 0.00 & 0.01 \\
\hline
\end{tabular}

Mean with the same letters $(a, b)$ on row are not significantly different at $\mathrm{P}=0,05$ depending of Student Newman Keuls test.

Those that are not assigned the letter have suffered the nonparametric Kruskal-Wallis test. 
Table 4: Mass and volume parameters almonds of the analysed shea kernels from different parks in Benin.

\begin{tabular}{|c|c|c|c|c|c|c|c|}
\hline Park & $\begin{array}{l}\text { 1000 kernels } \\
\text { Weight } \\
(\mathrm{kg})\end{array}$ & $\begin{array}{l}1000 \text { kernels } \\
\text { true Volume } \\
\left(\mathrm{dm}^{3}\right)\end{array}$ & $\begin{array}{l}1000 \text { kernels } \\
\text { bulk } \\
\text { Volume }\left(\mathbf{d m}^{3}\right)\end{array}$ & $\begin{array}{l}\text { True Density } \\
\left(\mathrm{kg} / \mathrm{m}^{3}\right)\end{array}$ & Density & $\begin{array}{l}\text { Bulk Density } \\
\left(\mathrm{kg} / \mathrm{m}^{3}\right)\end{array}$ & Specific area \\
\hline Savè & $3.98 \pm 0.39_{a}$ & $3.88 \pm 0.41_{\mathrm{a}}$ & $6.64 \pm 0.50_{a}$ & $1,024.24 \pm 23.19$ & $1.02 \pm 0.02$ & $598.12 \pm 30.79$ & $0.30 \pm 0.01_{\mathrm{ab}}$ \\
\hline Parakou & $4.38 \pm 0.72_{b}$ & $4.33 \pm 0.72_{b}$ & $7.51 \pm 1.20_{\mathrm{b}}$ & $1,011.15 \pm 17.71$ & $1.01 \pm 0.01$ & $582.61 \pm 25.00$ & $0.30 \pm 0.01_{\mathrm{a}}$ \\
\hline Bembèrèkè & $4.40 \pm 0.54_{b}$ & $4.37 \pm 0.58_{b}$ & $7.70 \pm 0.95_{b}$ & $1,007.51 \pm 22.40$ & $1.01 \pm 0.02$ & $571.77 \pm 17.23$ & $0.29 \pm 0.01_{\mathrm{a}}$ \\
\hline Kandi & $3.84 \pm 0.44_{\mathrm{a}}$ & $3.76 \pm 0.40_{\mathrm{a}}$ & $6.56 \pm 0.80_{a}$ & $1,019.30 \pm 31.48$ & $1.02 \pm 0.03$ & $585.78 \pm 27.30$ & $0.31 \pm 0.01_{\mathrm{b}}$ \\
\hline Mean & $4.15 \pm 0.58$ & $4.09 \pm 0.59$ & $7.10 \pm 1.02$ & $1,015.55 \pm 24.72$ & $1.02 \pm 0.02$ & $584.57 \pm 26.87$ & $0.30 \pm 0.01$ \\
\hline
\end{tabular}

\section{DISCUSSION}

Moisture content meets the international standard. But it was noticed that shea nuts are dried in poor conditions. They are often dried on the bare ground with no hygiene hence their exposure to microbial contamination. This call for the need to develop appropriate dryer that guarantee the safety of the product.

These results show that the size of the analysed shea kernels are smaller (about $5 \mathrm{~mm}$ on average) than those of northern Nigeria. The average sizes, reported by Aviara et al. (2000) on shea almonds collected in Michika, Adamawa State (Nigeria), are $29.62 \mathrm{~mm}$, $20.30 \mathrm{~mm}$ and $18.20 \mathrm{~mm}$ for length, thickness and width at moisture content of $3.84 \%(\mathrm{db})$, respectively. Taking into account the results of Aviara et al. (2005), showing an increase in kernels size with moisture content, it could be envisioned that the sizes reported by Aviara et al. (2000) is higher than the one reported in the current work (mean of $7.55 \pm 1.23 \%$ (w.b)). Olajide et al. (2000) reported $31.50 \mathrm{~mm} 23.70$ $\mathrm{mm}$ and $22.00 \mathrm{~mm}$ on shea kernels collected in the region of Ogbomosho (Nigeria) for length, height and width with a moisture content of $4.35 \%$ (d.b), respectively. On the over hand, Yé et al. (2004) reported average of $25.6 \mathrm{~mm}, 15.15 \mathrm{~mm}$ and $17.83 \mathrm{~mm}$ for length, width and thickness, respectively of shea kernels from Burkina Faso. These sizes are smaller than those reported in the current study and from Nigeria. This trend confirms previous observations on samples from
Simpérou village in Banikoara zone (Benin) where the average sizes of shea kernels are: $25.6 \mathrm{~mm}, 15.15 \mathrm{~mm}$ and $17.83 \mathrm{~mm}$ for length, width and thickness, respectively (Ahouansou et al., 2008). Further the observed difference between sizes from different parks could be related to the agricultural practices that encourage flowering, fruiting and seeds exchange (Kelly, 2005), but also to the combination of edaphic, climatic and anthropogenic factors. Indeed, rainfall pattern seems to have an impact on the sizes of shea nuts and their almonds. The measured rain quantity was $800 \mathrm{~mm}$ for Banikoara region that is located in the Sudanian zone together with Bobo Dioulasso (latitude of $11^{\circ} 00^{\prime} \mathrm{N}$ $12^{\circ} 00^{\prime} \mathrm{N}$ ) where the reported rain quantity was between 900 and $1,100 \mathrm{~mm}$ per year (Yé et al., 2004).

Olajide et al. (2000) reported a geometric diameter of $25.2 \mathrm{~mm}$ on shea kernels studied in Nigeria and confirmed that, generally the shea almonds from this country are bigger than those of Benin. Knowledge of the values of different diameters, arithmetic, geometric could permit establishing mathematical models for size's prediction of the shea almonds.

The value of sphericity confirm those of Ahouansou et al. (2008) who reported sphericity value of 0.74 for the shea kernels from Simpérou in the shea park of Kandi. Aviara et al. (2000) also reported that the sphericity of shea kernels collected in Michika, varies between 0.68 and 0.75 , while 
Olajide et al. (2000) reported an average sphericity of 0.80 on the shea kernels from Ogbomosho region.

Regarding porosity of shea kernels, the shea park of Savè showed the lowest value $41.59 \pm 3.08 \%$ while that of Bembèrèkè the highest $(43.24 \pm 1.47 \%)$. The knowledge on the shape is useful for the conception of adequate sheller and evaluation of its performance together with the development of mathematical models on shea kernels.

The observed trend for the mass and volume is in accordance with the shea kernels measurements. Ahouansou et al. (2008) reported that, the one-thousand weigh for shea kernels collected at Simpérou in Kandi's shea park was around $4 \mathrm{~kg}$, while the one determined for shea kernels from Burkina Faso was, on average of $2.49 \mathrm{~kg}$, at moisture content of $3.7 \%$ (Ye et al., 2004).

In Nigeria, the weight of one-thousand shea almonds, at moisture content of $5.66 \%$ (w.b), is on average $4.77 \mathrm{~kg}$ (Aviara et al., 1999; Aviara et al., 2000). It could be concluded that shea kernels of the different parks of Benin are heavier than those from Burkina Faso, but their weights remain slightly lighter than those from Nigeria. This significant differences could be imputed to several factors including the cultivated shea species or varieties, the climatic and production conditions. It is more observed that more profits is gained when purchasing shea kernels in the parks of Savè and Kandi because, at equal volume, the quantity of kernels is higher. The shea kernels sales being usually effected by volume unit, a cubic meter of shea kernels weighs between 585 and 598 $\mathrm{kg}$ in the shea parks of Kandi and Savè, whilst it weighs 571 and $582 \mathrm{~kg}$ in the shea parks of Parakou and Bembèrèkè. This is in agreement with the recorded bulk density of shea kernels (Table 4). The herein reported data can help to understand why majority of the shea almonds processors, during the period of the study have always thought, that small sizes shea nuts give significant amount of oils.

The density of almonds is generally a function of its compactness and texture but also depends on the moisture content (Godon et al., 1991). This could suggest that climatic and geographic variations could affect the shape and sizes of shea nuts, but with no significant effect on their texture and compactness. If the results obtained by Aviara et al. (2000) have enabled the development of a shea nuts sheller (Oluwole et al., 2004), the current knowledge and data will allow for a better adaptation/adoption of this equipment in Benin conditions.

\section{Conclusion}

This study has been devoted to the physical characterization of shea nuts in four out of the five shea parks of Benin: Savè, Parakou, Kandi and Bembèrèkè. Emphasis was on the variability of the physical characteristics of shea almonds, mainly to those related to their sizes or measurements (length, width, thickness), shape, density (true and bulk) but also mass and volume of onethousand nuts. The obtained results have demonstrated that the shea park of Bembèrèkè produces the biggest nuts whereas the shea park of Kandi provides the smallest. Models describing the evolution of length, width and thickness on the basis of the average diameter of trees have been established. Shea kernels are not really spherically sharped but only at average ratio of $72 \%$. A Shea kernel of Savè park has the lowest porosity (41.59\%) while those from Bembèrèkè have the highest. The shea parks of Savè and Kandi have the lightest shea kernels while those of Parakou and Bembèrèkè, the heaviest with a one-thousand weight of 4.38 and $4.40 \mathrm{~kg}$ respectively. In terms of mass and volume, there is a similarity between the shea parks of Savè and Kandi on the one hand and the shea parks of Parakou and Bembèrèkè, on the other hand.

Knowledge of the physical properties of shea kernels, depending on the different parks, is not in itself sufficient to address the design of processing equipment. In addition, information and knowledge on the breaking strength of almonds and the mechanical properties such as elasticity and plasticity according to shea parks are required. Hence, it 
is essential to explore such a mechanical study, not only to almonds, but also to entire shea nuts!

\section{COMPETING INTERESTS} interests.

The authors declare no competing

\section{AUTHORS' CONTRIBUTIONS}

RHA worked in each step of the elaboration of this paper. PBA worked on the data collection, and analysis. EAS worked on the data analysis, writing and the correction of the paper. BG worked on the writing and the correction of the manuscript. PF worked on the data collection and analysis steps.

\section{ACKNOWLEDGEMENTS}

The authors express their gratitude to all those who, in any way or another, morally, physically or materially, enabled the realization of this study. Special thanks to women, nuts processors in shea parks of Savè, Parakou, Bembereke, Kandi and Bohicon, Standards and Trade Development Facilities (STDF) Project officials, all staff of Agriculture Program and Food Technology (PTAA), Agricultural Policy Analysis Program (PAPA), and Agricultural Research Centre of Agonkanmey at National Institute of agricultural research of Benin (INRAB).

\section{REFERENCES}

Abdul-Mumeen I, Zakpaa HD, MillsRobertson FC. 2013. Biochemical and microbiological analysis of shea nut cake: A waste product from shea butter processing, Journal of Agricultural Biotechnology and Sustainable Development, 5(4): 61-68. DOI: $0.5897 / \mathrm{JABSD} 12.031$.

Adeola RG. 2012 Perception of shea nut tree as an economic tree among farmers in Oyo State, Nigeria. International Journal of Agricultural Management \& Development (IJAMAD), 2(2): 85-89. http://www.ejmanager.com

Agbobatinkpo PB , Babade SD, Laleye F., Akissoe N, Azokpota P, Hounhouigan
JD. 2011. Softening effect of Ikpiru and Yanyanku, two traditional additives used for the fermentation of African Locust Bean (Parkia biglobosa) seeds in Benin. Int. J. Biol. Chem. Sci., 6(3): 1281-1292. DOI: http://dx.doi.org/10.4314/ijbcs.v6i3.31.

Ahouansou RH, Aïssi MV, Sanya EA, Soumanou MM. 2012. Propriétés physique et mécanique des graines de Pentadesma butyracea produites au Bénin; Journal of Applied Biosciences 50: 3485- 3493. http://www.m.elewa.org

Ahouansou RH, Sanya EA, Bagan G, Foudjet EA. 2008. Etude de quelques caractéristiques physiques des noix et amandes de karité produites au Benin. Sciences et techniques. Sci. Appl. Technol., 1(2): 29-38.

Aviara NA, Oluwole FA, Haque MA. 2005. Effect of moisture content on some physical properties of sheanuts (Butyrospernum paradoxum). Int. Agrophysics, 19: 193-198. https://www.researchgate.net/publication/ 26551639.

Aviara NA, Haque MA, Izge IA. 2000. Physical and frictional properties of sheanuts. Agro- Sci. Jour., 1: 19-34. http://dx.doi.org/10.4314/as.v1i2.1452

Boussim IJ, Yonli D, Medah MN, Guinko S, Sallé G. 2012. Prospects for an integrated control of Loranthaceae species parasitizing Vitellaria paradoxa C. F. Gaerth in Burkina Faso. Int. J. Biol. Chem. Sci., 6(1): 355-364. DOI: http://dx.doi.org /10.4314/ijbcs.v6i1.31

CNUCED. 2008. Centre des Nations Unies pour le Commerce et le Développement: Informations de marché dans le secteur des produits de base. Informations sur le karité. http: //www. r0.unctad.org /infocomm /francais /karite /culture.htm\# rendements / 15/01/2010

Fatoumata C, Soronikpoho S, Souleymane T, Kouakou B, Marcellin DK. 2016. Caractéristiques biochimiques et microbiologiques de moutardes africaines produites à base de graines fermentées de 
Parkia biglobosa et de Glycine max, vendues en Côte d'Ivoire. Int. J. Biol. Chem. Sci., 10(2): 506-518. DOI: http://dx.doi.org/10.4314/ijbcs.v10i2.5

FAOSTAT. 2010. Base de données de la FAO. On http://www.faostat.fao.org/10/09/2010.

Glele Kakaï R, Sodjinou E, Fonton N. 2006. Conditions d'application des méthodes statistiques paramétriques : applications sur ordinateur; Bibliothèque Nationale, Bénin.

Glèlè Kakaï R., Kokode G. 2004. Techniques statistiques univariées et multivariées: applications sur ordinateur. Bibliothèque Nationale, Bénin.

Gnangle CP, Honfo SH, Gbemavo C. 2016. Agrarian systems dynamics of shea trees (Vitellaria paradoxa Gaertn) parklands in Northern Benin. Int. J. Biol. Chem. Sci., 10(1): 13-22. DOI : http://dx.doi.org/10.4314/ijbcs.v10i1.2.

Gnanglè PC. 2005. Parcs à karité (Vitellaria paradoxa) (Gaertn. C. F.) (Sapotaceae) au Bénin: Importance socio-culturelle, caractérisation morphologique, structurale et régénération naturelle. Mémoire de DEA, FSA/UAC (ed), Campus UAC, Bénin, p 113.

Honfo FG, Kerstin H, Akissoé N, Linnemann A, Coulibaly O. 2012. Microbiological and physicochemical characterization of shea butter sold on Benin markets. Journal of Stored Products and Postharvest Research, 3(3): 24-29. DOI: 10.5897/JSPPR11.045

Honfo FG, Linnemann AR, Akissoe N, Soumanou MM, van Boekel MAJS. 2013. Characteristics of traditionally processed shea kernels and butter, International Journal of Food Science \& Technology, 48(8): 1714-1721. DOI: 10.1111 /ijfs. 12142

Kelly BA. 2005. Impact des pratiques humaines sur la dynamique des populations et sur la diversité génétique de Vitellaria paradoxa (karité) dans les systèmes agro forestiers au sud Mali. Thèse de Doctorat. Institut Supérieur de
Formation et Recherche Appliquée, Univ. du Mali, p212.

Koura K, Yéba Mbaide Y, Ganglo JC. 2013. Caractéristiques phénotypique et structurale de la population de Parkia biglobosa (Jacq.) R. Br. du Nord-Bénin. Int. J. Biol. Chem. Sci., 7(6): 2409-2425. DOI: http://dx.doi.org/10.4314/ijbcs.v7i6.19

Kouyate AM, Dembele U, Lykke AM, 2015. Les espèces ligneuses locales à huile : une ressource utile pour les communautés locales au Sud du Mali. Int. J. Biol. Chem. Sci., 9(6): 2754-2763. DOI : http://dx.doi.org/10.4314/ijbcs.v9i6.19

Makalao MM, Savadogo A, Zongo CS, Traore AS. 2015. Composition nutritionnelle de 10 fruits sauvages consommés dans trois départements du Tchad. Int. J. Biol. Chem. Sci., 9(5): 2385-2400. DOI: http://dx.doi.org/10.4314/ijbcs.v 9i5.11

Maranz S, Wiesman Z. 2004. Influence of climate on the tocophenol content of shea butter. Journal of Agricultural and Food Chemistry, 52: 2934-2937. DOI:10. 1021/jf035194r

Meisami-asl E, Raffiee S, Keyhani A, Tabataeefar A. 2009. Some physical properties of Apples cv. 'Golab' Agr. Ing. Int.: The CIGR Ejournal. Manuscript 1124. XI. http://www.cigrjournal.org

Nde Bup D, Mohagir AM, Kapseu C, Mouloungui Z. 2014. Production zones and systems, markets, benefits and constraints of shea (Vitellaria paradoxa Gaertn) butter processing. OCL, 21(2) D206. DOI: $10.1051 / \mathrm{ocl} / 2013045$

Olajide JO, Ade-Omowaye BIO, Otunola ET. 2000. Some physical properties of shea kernel. Jour. Agric. Ing. Res., 76(4): 419421.

Oluwolé FA, Aviara NA, Haque MA. 2007. Effet of moisture content and impact energy on crackability of sheanut. Agric. Eng. Int.: The CIGR Ejournal. Manuscript FP 007002 , IX. https.//ecommons.cornell.edu

Oluwolé FA, Aviara NA, Haque MA. 2004. Development and performance test of 
sheanut craker. Jour. Food Eng., 65: 117 $-123$.

http://dx.doi.org/10.1016/j.jfoodeng. 2004.01.004

Ouattara CAT, Somda MK, Moyen R, Traore AS. 2015. Comparative physicochemical and proximate analysis of oils of Shea nut, Sesamum indicum, Cucurbita pepo, Cucumis melo seeds commonly cultivated in West Africa. African Journal of Biotechnology, 14(31) : 24492454. DOI: $10.5897 / A J B 2015.14642$

Rantrua S. 2004. Un marché, une concentration d'acteurs. Marchés Tropicaux, 59(3078): 2436-2437. http://www.africabib.org/rec.php?RID=2 87917134

Singbo A, Ahouansou R. 2005. Etude de faisabilité de l'implantation d'un atelier mécanisé de production de beurre de karité au Bénin (Afrique de l'Ouest). Bull. Rech. Agr. Bénin (BRAB), 50: 3846.
Tame VT, Hassan I, Gungula DT. 2015. Influence of heating time of shea nuts (Vitellaria paradoxa) on some chemical properties of shea butter. World Journal of Engineering and Technology, 3: 13-18. http://dx.doi.org/10.4236/wjet.2015.33 B003

Tiamiyu SA, Adagba MA, Shaahu A. 2014. Profitability analysis of shea nuts supply chain in selected states in Nigeria. Journal of Agricultural and Crop Research, 2(12): 222-227. http://sciencewebpublishing.net/jacr/

Yê GS, Destain MF. 2004. Etude d'une presse à huile: Caractérisation technique des presses manuelles à karité existant au Burkina Faso et détermination de l'effort de concassage de l'amande de karité. Mémoire DEA. Sciences Agronomiques et Ingénierie biologique. Faculté Universitaire des Sciences Agronomiques de Gembloux, p75. 